\title{
Capacity of soil loss control in the Loess Plateau based on soil erosion control degree
}

\author{
GAO Haidong ${ }^{1,2}$, "LI Zhanbin ${ }^{1,2}$, JIA Lianlian ${ }^{3}$, Li Peng ${ }^{1}$, XU Guoce ${ }^{1}$, \\ REN Zongping ${ }^{1}$, PANG Guowei ${ }^{4}$, ZHAO Binhua ${ }^{1}$
}

1. State Key Laboratory Base of Eco-hydraulic Engineering in Arid Area (Xi'an University of Technology), Xi'an 710048, China;

2. State Key Laboratory of Soil Erosion and Dryland Agriculture on Loess Plateau, Institute of Soil and Water Conservation, Chinese Academy of Sciences and Ministry of Water Resources, 712100, Yangling, Shaanxi, China;

3. Upper and Middle Yellow River Bureau, Yellow River Conservancy Commission of the Ministry of Water Resources, Xi'an 710021, China;

4. College of Urban and Environmental Science, Northwest University, Xi'an 710127, China

\begin{abstract}
The capacity of soil and water conservation measures, defined as the maximum quantity of suitable soil and water conservation measures contained in a region, were determined for the Loess Plateau based on zones suitable for establishing terraced fields, forestland and grassland with the support of geographic information system (GIS) software. The minimum possible soil erosion modulus and actual soil erosion modulus in 2010 were calculated using the revised universal soil loss equation (RUSLE), and the ratio of the minimum possible soil erosion modulus under the capacity of soil and water conservation measures to the actual soil erosion modulus was defined as the soil erosion control degree. The control potential of soil erosion and water loss in the Loess Plateau was studied using this concept. Results showed that the actual soil erosion modulus was $3355 \mathrm{t} \cdot \mathrm{km}^{-2} \cdot \mathrm{a}^{-1}$, the minimum possible soil erosion modulus was $1921 \mathrm{t} \cdot \mathrm{km}^{-2} \cdot \mathrm{a}^{-1}$, and the soil erosion control degree was 0.57 (medium level) in the Loess Plateau in 2010. In terms of zoning, the control degree was relatively high in the river valley-plain area, soil-rocky mountainous area, and windy-sandy area, but relatively low in the soil-rocky hilly-forested area, hilly-gully area and plateau-gully area. The rate of erosion areas with a soil erosion modulus of less than $1000 \mathrm{t} \cdot \mathrm{km}^{-2} \cdot \mathrm{a}^{-1}$ increased from $50.48 \%$ to $57.71 \%$, forest and grass coverage rose from $56.74 \%$ to $69.15 \%$, rate of terraced fields increased from $4.36 \%$ to $19.03 \%$, and per capita grain available rose from 418 $\mathrm{kg} \cdot \mathrm{a}^{-1}$ to $459 \mathrm{~kg} \cdot \mathrm{a}^{-1}$ under the capacity of soil and water conservation measures compared with actual conditions. These research results are of some guiding significance for soil and water loss control in the Loess Plateau.
\end{abstract}

Keywords: Loess Plateau; soil erosion control degree; control potential of soil erosion and water loss; RUSLE

Received: 2015-09-17 Accepted: 2015-10-20

Foundation: National Natural Science Foundation of China, No.41401305; No.41330858; The Open Foundation of State Key Laboratory of Soil Erosion and Dryland Farming on the Loess Plateau, No.K318009902-14

Author: Gao Haidong (1983-), PhD, specialized in soil erosion and remote sensing. E-mail: hdgao@xaut.edu.cn

"Corresponding author: Li Zhanbin, Professor, E-mail: zbli@ms.iswc.ac.cn 


\section{Introduction}

The Loess Plateau is located in the northern hinterland of China, and forms a significant portion of the Yellow River Basin. The major environmental problem in the Loess Plateau is serious soil erosion and water loss. According to the Comprehensive Scientific Survey of Soil Erosion and Water Loss and Ecological Safety in China, the Loess Plateau with a total area of $64 \times 10^{4} \mathrm{~km}^{2}$ has soil erosion area up to $39 \times 10^{4} \mathrm{~km}^{2}$, including severe water erosion area of $3.67 \times 10^{4} \mathrm{~km}^{2}$ with soil erosion modulus $\geqslant 15,000 \mathrm{t} \cdot \mathrm{km}^{-2} \cdot \mathrm{a}^{-1}$, which accounts for $89 \%$ of similar areas in China (MWR, PRC et al., 2010). The serious soil erosion and water loss in the Loess Plateau restrains local socio-economic development and seriously threatens the flood control safety in the downstream channel, so it has attracted widespread attention from scholars at home and abroad; concentrated rainstorms, loose loess, low vegetation coverage, and unreasonable human activities are the main causes for the serious soil erosion in the Loess Plateau (Fu et al., 2011; Dotterweich, 2013; Sun et al., 2014; Wang et al., 2015; Zhao et al., 2014; Jiao et al., 2014).

To prevent the serious soil erosion and water loss, the Chinese government has taken a series of soil and water conservation measures, such as adjusting land use structure, recovering vegetation, improving tillage practice, building terraces on slopes, and constructing check dams in channels (Zhu, 2012; Bullock et al., 2011). As of 2010 (UMRYRAB, 2011), more than 90,000 check dams of various types had been constructed to form $28.63 \times 10^{4}$ ha of dam farmland, $281.85 \times 10^{4}$ ha of terraces had been built, and $968.28 \times 10^{4}$ ha of forest had been planted. The implementation of large-scale soil and water conservation programme has caused sharp decrease in sediment discharge in the Yellow River, for example, the average sediment discharge measured at Sanmenxia hydrologic station was $16 \times 10^{8} \mathrm{t}$ during 1919-1960, but it was $6 \times 10^{8} \mathrm{t}$ during 1990-2007, decreasing by $10 \times 10^{8} \mathrm{t}$, of which $50 \%-60 \%$ was caused by rainfall-induced sediment reduction and $40 \%-50 \%$ was caused by soil and water conservation measures (YRCC, MWR, 2013). The sediment reduction effect of soil and water conservation measures has been studied in depth by scholars from China and other countries; the soil conservation measures primarily include terracing, check dam building, and returning cultivated land to forest (grassland), and the study areas are mainly concentrated in the source region of centralized coarse sediments in the Hekou-Longmen section of the middle reaches of the Yellow River (Yao et al., 2013). Liu et al. (2014) believed that the sediment reduction effect of the level terraces in the Loess Plateau has been most probably underestimated, and the sediment reduction potential of ridged level terraces in the river basins can be up to $65 \%-90 \%$; when the terrace percentage is more than $35 \%-40 \%$, the sediment reduction effect of the terraces is basically stabilized at about $90 \%$. Zhang et al. (2009) through study indicated that the influence degree of the human activities, including land use/cover changes, in the Hekou-Longmen section of the middle reaches of the Yellow River on the decrease in runoff in the river basin is over $50 \%$. The construction of check dams has enabled significant change in the original relationship between sediment transport and sedimentation in the river basin. Research results show that, in natural conditions, the sediment delivery ratios of the river basins in the Loess Plateau are generally about 1 , and decrease significantly with the construction of dam and reservoir projects, for example, the sediment delivery ratio in the Wuding River basin decreases to $0.2-0.4$ (Xu et al., 2004). 
The common index currently used for characterizing river basin governance degree is soil erosion and water loss governance degree ( $\mathrm{Su}$ et al., 2011), namely, "ratio of the area of the regions with soil erosion and water loss governance measures taken to the area of the regions having soil erosion and water loss in a river basin (region)". However, governance degree cannot accurately reflect the governance level of a river basin; for some river basins, the soil erosion and water loss governance degree may have reached $100 \%$, yet there are still soil erosion and water loss areas to be further governed, so the ratio of governance area to soil erosion and water loss area cannot comprehensively reflect the status of governance recovery (erosion control) of a small catchment. The slope farmlands account for about $2 / 3$ of the total farmland area in the Loess Plateau, and are the main source of soil and water loss in the Loess Plateau, with average soil erosion modulus up to $25,000 \mathrm{t} \cdot \mathrm{km}^{-2} \cdot \mathrm{a}^{-1}$ (Gao et al., 2012). There are primarily two ways for converting the slope farmlands in the Loess Plateau: one is converting slopes into terraces, and the other is returning cultivated land to forest (grassland). There are currently few reports on soil and water conservation measures and slope farmland conversion potential in the Loess Plateau.

This paper, with the whole Loess Plateau as a study object, firstly defines the concept of soil erosion control degree and determines the calculation method for the capacity of soil and water conservation measures; secondly analyzes the capacity of soil and water conservation measures and the characteristics of soil erosion control degree of the whole Loess Plateau; and finally discusses the soil erosion and land use structure changes in the Loess Plateau under the capacity of soil and water conservation measures and analyzes the grain yield level in the Loess Plateau under the capacity of soil and water conservation measures. It is expected that the research results will provide scientific bases for soil and water conservation works in the Loess Plateau.

\section{Materials and methods}

\subsection{Study region}

The Loess Plateau is located between $100^{\circ} 52^{\prime}-114^{\circ} 33^{\prime} \mathrm{E}$ and $33^{\circ} 41^{\prime}-41^{\circ} 16^{\prime} \mathrm{N}$, and contains seven provinces and autonomous regions, i.e., Qinghai, Gansu, Ningxia, Inner Mongolia, Shaanxi, Shanxi, and Henan, with a total area of $64.62 \times 10^{4} \mathrm{~km}^{2}$. The Loess Plateau suffers very serious soil erosion and water loss, with complex and diverse erosion types. Soil erosion and water loss make up an area of $39.08 \times 10^{4} \mathrm{~km}^{2}$, which includes water and wind erosion areas of $33.41 \times 10^{4} \mathrm{~km}^{2}$ and $5.67 \times 10^{4} \mathrm{~km}^{2}$, respectively.

The Loess Plateau surface is primarily covered by loess deposits (50-200 m deep) distributed in a relatively continuous manner, with high terrain in the northwest and low terrain in the southeast. Based on natural conditions, such as topography and geomorphology, as well as soil erosion features, the plateau can be zoned into six areas, namely, plateau-gully area, hilly-gully area, river valley-plain area, soil-rocky mountainous area, windy-sandy area, soil-rocky hilly-forested area (hereafter hilly-forested area for short) (Figure 1). The climate is continental monsoon, with rainstorms in the hot summer and autumn, and high winds and sand storms during the cold, dry winter and spring. The multi-year average temperature is $9-12^{\circ} \mathrm{C}$, and multi-year average annual precipitation ranges from 200 to $700 \mathrm{~mm}$ from the northwest to the southeast; rainfall concentrations generally from June to September, with 
rainstorm in domination. The centralized precipitation accounts for over $60 \%$ of the annual total. There are 48 tributaries, each with an area over $1000 \mathrm{~km}^{2}$, directly flowing into the Yellow River, with surface water in the whole region covering an area of $105.56 \times 10^{8} \mathrm{~m}^{3}$. Vegetation can be divided into forest, forest-steppe, typical steppe, desert-steppe, and steppe-desert zones from the southeast to the northwest. The area is dominated by loessial soil, with a grain composition of fine sand and silt, a relatively uniform texture, and a loose, soft body with soil bulk density of $1.1-1.3 \mathrm{t} / \mathrm{m}^{3}$ and total porosity of $50 \%-60 \%$. Due to serious soil erosion and water loss, the soil is of relatively poor quality.

The Loess Plateau region incorporates 44 prefectures (cities) and 305 counties (banners) from seven provinces (autonomous regions). In 2011, the population density was 178.23 people $\cdot \mathrm{km}^{-2}$ and the total population was $11517.52 \times 10^{4}$, including an agricultural population of $7547.37 \times 10^{4}$, accounting for $65.53 \%$ of the total population. The annual per capita net income for farmers is $3200 \mathrm{RMB}$ yuan, and thus economic development is relatively low.

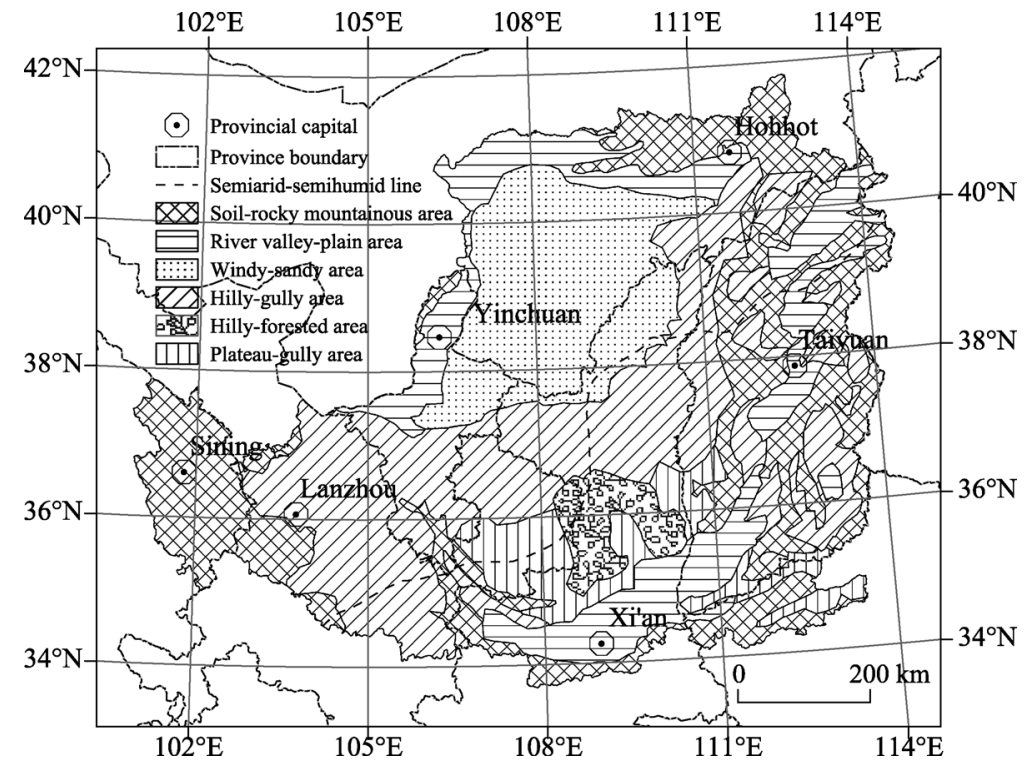

Figure 1 Zoning map of the Loess Plateau

\subsection{Data collection and analysis}

The digital elevation model (DEM) dataset was provided by the Geospatial Data Cloud, Computer Network Information Center, Chinese Academy of Sciences (http://www.gscloud. $\mathrm{cn}$ ), and was obtained by processing the data from ASTER GDEM (V1), with projection type UTM/WGS84 and a spatial resolution of $30 \mathrm{~m}$.

The soil type map was provided by the Cold and Arid Regions Sciences Data Center at Lanzhou (http://westdc.westgis.ac.cn), and included the China region subset of the Harmonized World Soil Database (HWSD) (Gunther et al., 2008). The data were in grid format. The spatial resolution was $1 \mathrm{~km}$, the geographic coordinate system was WGS84, and the soil classification system used was FAO-90.

The land use data were from the 1:100,000 Land Use Database of China 2010, which was obtained using the human-computer interaction quick interpretation method on the basis of 
images from Landsat TM and Chinese environmental mitigation HJ1 satellite. Assessments showed that the classification accuracy of Class I land use types was $94 \%$ and that of Class II was $91 \%$ (Liu et al., 2014). In this land use classification system, farmlands were divided into paddy field and dry farmland; in the Loess Plateau, dry farmlands were further divided into irrigated land, terraced field, dam farmland, and slope farmland. Data on the area of irrigated land were from agricultural statistical yearbooks of each county (NBS, PRC, 2012), and the terraced and dam farmland data were obtained from remote sensing and statistical investigation conducted by the Upper and Middle Yellow River Bureau, Yellow River Conservancy Commission (YRBMC, 2011).

The rainfall data were from the China Meteorological Data Sharing Service System (http://cdc.nmic.cn), and the 30 years of monthly precipitation data were collected from 108 state-level weather stations in and around the Loess Plateau.

Population data were obtained from the Population Statistics for Counties and Cities of the PRC (2011) published by the Administration Bureau for Public Order, Ministry of Public Security of the People's Republic of China. The farmland data and grain yield per unit area were obtained from statistical yearbooks, literature analysis and field questionnaires.

\subsection{Analytical method}

\subsubsection{Concept of soil erosion control degree}

Soil erosion control degree is the ratio of minimum possible soil erosion modulus to actual soil erosion modulus (Gao et al., 2013), that is,

$$
r=T_{0} / T_{s}
$$

where $r$ is soil erosion control degree, dimensionless; $T_{0}$ is the minimum possible soil erosion modulus, that is, the soil erosion modulus under capacity of soil and water conservation measures, $\mathrm{t} \cdot \mathrm{km}^{-2} \cdot \mathrm{a}^{-1} ; T_{s}$ is the actual soil erosion modulus, $\mathrm{t} \cdot \mathrm{km}^{-2} \cdot \mathrm{a}^{-1}$. The soil erosion control degree is within $0-1$, reflecting the degree of proximity to the ideal governance state of soil and water conservation; the closer the $r$ is to 1 , the higher the governance degree, and the closer the $r$ is to 0 , the lower the governance degree, that is, it deviates farther from the ideal governance state.

\subsubsection{Capacity of soil and water conservation measures in the Loess Plateau}

Capacity of soil and water conservation measures is defined as the maximum quantity of suitable soil and water conservation measures containable in an area, and it reflects the governance potential of soil and water conservation in an area. The concept of the capacity of soil and water conservation measures reflects the principle of "adaptation to local condition" in governance of soil and water conservation. According to the site requirements of different soil and water conservation measures, all suitable distribution zones of each measure are found, and then the soil and water conservation measures are laid out; after the measures are laid out, all governance works have been completed theoretically for the area, with the soil erosion modulus controlled at a reasonable level, and the quantity of soil and water conservation measures in this case is called capacity of soil and water conservation measures. Priority sequence should be taken into account in laying out soil and water conservation measures; in the Loess Plateau, the priority sequence is generally as follows: terrace $\rightarrow$ forestland $\rightarrow$ grassland. When a site meets the requirements for layout of all of the above three meas- 
ures in the same time, the priority sequence is terrace, followed by forestland, and finally grassland.

(1) Suitable areas for terrace in the Loess Plateau

The loess region has thick soil layer, and slope-to-terrace is the main governance measure for gentle slope areas. The suitable areas for terrace in the Loess Plateau set in this paper meet the following conditions: original hilly-gully area and plateau-gully area used as farmlands shall have a slope less than $15^{\circ}$, while soil-rocky mountainous area, windy-sandy area, river valley-plain area and hilly-forested area shall have a slope less than $5^{\circ}$ due to thinner soil layer.

(2) Suitable areas for forestland in the Loess Plateau

The growth of trees in the forestlands is primarily restricted by rainfall condition, and some scholars pointed out that the suitable areas for forest in the Loess Plateau should have more than $400 \mathrm{~mm}$ of precipitation but some others thought that the precipitation threshold for the suitable areas for forest should be $450 \mathrm{~mm}$ (Jiang, 1997; Li et al., 2008). The main landscape is steppe in semi-arid areas and forest steppe in semi-humid areas. Therefore, it was believed through this study that semi-humid areas and humid areas are suitable distribution areas for forestland, and semi-arid areas and arid areas are suitable distribution areas for grassland. For the semi-arid and semi-humid boundary, the climatic regionalization proposed by Zheng et al. (2010) was directly used in this paper. Consequently, the suitable distribution areas for forestland include: the existing forestlands; soil-rocky mountainous area, forested area, windy-sandy area and river valley-plain area having slope farmlands with slope more than $5^{\circ}$ located in semi-humid areas; and hilly-gully area and plateau-gully area having slope farmlands with slope more than $15^{\circ}$ located in semi-humid areas.

(3) Suitable areas for grassland in the Loess Plateau

In addition to the terraces and forestlands in the above areas, grasslands are laid out in other areas, so the suitable areas for grassland include: the existing grasslands; soil-rocky mountainous area, hilly-forested area, windy-sandy area and river valley-plain area having slope farmlands with slope more than $5^{\circ}$ located in semi-arid areas; hilly-gully area and plateau-gully area having slope farmlands with slope more than $15^{\circ}$ located in semi-arid areas; and sandy lands.

The layout area of the soil and water conservation measures in the above cases is called capacity of soil and water conservation measures, and the soil erosion modulus calculated on this basis is defined as minimum possible soil erosion modulus. The slopes were extracted using the digital elevation model (DEM) and subdivided into four classes, i.e., $0-5^{\circ}, 5^{\circ}-15^{\circ}$, $15^{\circ}-25^{\circ}$, and $>25^{\circ}$. The capacity of soil and water conservation measures in the Loess Plateau was obtained through discriminant analysis using the criteria function, under the support of the spatial model of the ERDAS IMAGINE9.1 software and with the existing land use map and climate zoning map. The terraces are $1229.31 \times 10^{4}$ ha, the forestlands are $1248.72 \times 10^{4} \mathrm{ha}$, and the grasslands are $3219.16 \times 10^{4}$ ha, accounting for $19.03 \%, 19.33 \%$, and $49.82 \%$ of the total area of the Loess Plateau, respectively.

\subsubsection{Determination of soil erosion modulus using RUSLE}

The soil erosion modulus was determined using the revised universal soil loss equation (RUSLE) supported by the ArcGIS software (Kenneth et al., 1997), and the expression is:

$$
A=R \cdot K \cdot S \cdot L \cdot C \cdot P
$$


where $A$ is the average annual soil loss, $\mathrm{t} \cdot \mathrm{km}^{-2} \cdot \mathrm{a}^{-1} ; R$ is the rainfall-runoff erosivity factor, $\mathrm{MJ} \cdot \mathrm{mm} \cdot \mathrm{ha}^{-1} \cdot \mathrm{h}^{-1} \cdot \mathrm{a}^{-1} ; K$ is the soil erodibility factor, $\mathrm{t} \cdot \mathrm{ha} \cdot \mathrm{h} \cdot \mathrm{ha}^{-1} \cdot \mathrm{MJ}^{-1} \cdot \mathrm{mm}^{-1} ; S$ is the slope steepness factor; $L$ is the slope length factor; $C$ is the cover-management factor; and $P$ is the supporting-practice factor.

(1) Rainfall-runoff erosivity factor (R)

The empirical equation for rainfall erosivity with monthly precipitation, as proposed by Wischmeier et al. (1978), was used to calculate multi-year average rainfall erosivity:

$$
R=\sum_{i=1}^{12}\left(1.735 \times 10^{1.5 \times \lg \frac{P_{i}^{2}}{P}-0.8188}\right)
$$

where $P$ and $P_{i}$ are average annual and monthly precipitations, respectively, $\mathrm{mm}$.

The multi-year average rainfall erosivity $(\mathrm{R})$ value was calculated with Eq. (3) based on the monthly precipitation data collected in the study region; semivariance function simulation was conducted in GS+7.0 to find the optimal model. Kriging interpolation was carried out using the Gaussian model in the ArcGIS geostatistical module to obtain the rainfall erosivity factor of the whole Loess Plateau (Figure 2a).

(2) Soil erodibility factor (K)

Estimation of the soil erodibility $(\mathrm{K})$ value was conducted with organic matter and particle composition of soil using the soil erosion-productivity impact calculator (EPIC) (Sharpley and Williams, 1990):

$$
\begin{gathered}
K=0.1317 *\{0.2+0.3 \exp [-0.0256 S A N(1-S I L / 100)]\} *[S I L /(C L A+S I L)]^{0.3 *} \\
\{1.0-0.25 C /[C+\exp (3.72-2.95 C)]\} *\left\{1.0-0.7 S N_{1} /\left[S N_{I}+\exp \left(-5.51+22.9 S N_{l}\right)\right]\right\}
\end{gathered}
$$

where $S A N$ is the sand fraction, $\% ; S I L$ is the silt fraction, \%;CLA is the clay fraction, \%; $C$ is the soil organic carbon content, $\%$; and $S N_{1}=1-S A N / 100$. The soil erodibility $K$ value of the whole study region was calculated according to the soil type map and attribute data of the Loess Plateau (Figure 2b).

(3) Slope steepness and slope length factor (LS)

The LS calculation was based on the following expressions of McCool et al. (1989) used in the RUSLE:

$$
\begin{gathered}
S=10.8 \sin \theta+0.03 \theta<9 \% \\
S=16.8 \sin \theta-0.5 \theta \geqslant 9 \% \\
L=(\lambda / 22.1)^{m}
\end{gathered}
$$

where $\lambda$ is the horizontal projection length of the slope, $\mathrm{m} ; m$ is the available length-slope exponent, and $\theta$ is the slope angle.

The LS factor values of the whole Loess Plateau were calculated using the LS factor calculation tool developed by Zhang et al. (2013), based on the $30 \mathrm{~m}$ DEM data of the Loess Plateau, with the whole Loess Plateau divided into eight sub-regions with the main rivers as boundaries (Figure 2c).

(4) Cover-management factor (C)

According to the research results from Zhang $(2001,2003)$ and Jiao et al. (2009) the C values of the main crops in the hilly-gully areas of the Loess Plateau are as follows: 0.28 for corn, 0.51 for beans, 0.47 for potatoes, and 0.53 for millet. The main crops in the gentle slope farmlands with slope less than $5^{\circ}$ in the Loess Plateau are corn and wheat, whose $\mathrm{C}$ 

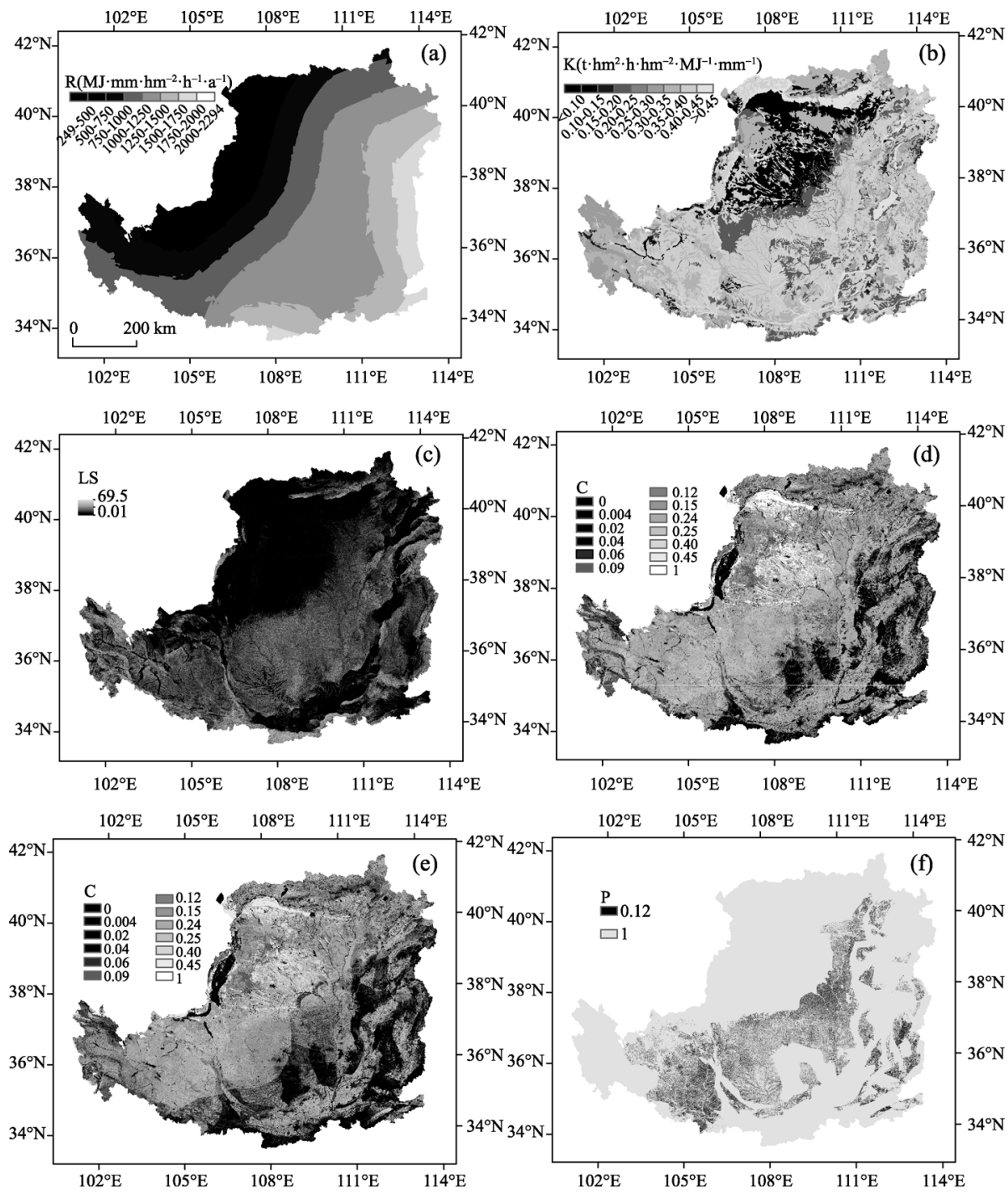

Figure 2 Various factor values from RUSLE for the Loess Plateau (a. rainfall erosivity factor (R); b. soil erodibility factor (K); c. slope length and steepness factor (LS); d. cover-management factor under actual conditions (C); e. cover-management factor under capacity of soil and water conservation measures (C); f. supporting-practice factor $(\mathrm{P})$ )

value is set as 0.25 . The crops in the slope farmlands with slope more than $5^{\circ}$ are dominated by beans, potatoes, and millet, and the $\mathrm{C}$ value is set as 0.40 . The $\mathrm{C}$ value for paddy fields, water areas and building lands is set as 0 , and that for unused lands is set as 1 . For the forestlands and grasslands, the $\mathrm{C}$ values are taken from Table 1 depending on vegetation coverage. The $\mathrm{C}$ factor distribution map was obtained based on the land use type map of the Loess Plateau in 2010 (Figures 2d and 2e).

Table $1 \mathrm{C}$ values at different vegetation coverage in the Loess Plateau

\begin{tabular}{cccccc}
\hline Vegetation coverage (\%) & $0-20$ & $20-40$ & $40-60$ & $60-80$ & $80-100$ \\
\hline Forestland & 0.25 & 0.12 & 0.06 & 0.02 & 0.004 \\
Grassland & 0.45 & 0.24 & 0.15 & 0.09 & 0.043 \\
\hline
\end{tabular}


(5) Supporting-practice factor (P)

The soil layer is thick in most parts of the Loess Plateau, so terrace is the predominant slope governance measure. Based on the multi-site monitoring data acquired in the Loess Plateau, Ran et al. (2006) believed that rainfall of individual rain events with precipitation more than $100 \mathrm{~mm}$ and less than $200 \mathrm{~mm}$ can almost completely be retained by terraces without runoff generated. Terraces retain runoff to reduce the runoff scouring to slope surfaces and valleys, decreasing the soil erosion amount. The existing research efforts mostly focus on the "in situ" sediment reduction effect of terraces, that is, the sediment reduction amount of a plot after the slope is transformed into terraces. In addition, terraces have "ex situ" sediment reduction effect, which is primarily reflected in two aspects: one is that terraces can intercept the sediment-laden water flow from above, and the other is that the flow velocity of the slope runoff flowing through terraces will be lowered, thereby reducing the slope erosion amount below the terraces. Liu et al. (2014) thought that the sediment reduction effect of terraces has probably been underestimated for a long time due to the neglect of the "ex situ" sediment reduction effect of terraces. The spatial layout of terraces can also influence the sediment reduction benefit (Zhang et al., 2014), and terraces having the same area follow the law of "the upper part being better than the lower one" in respect of spatial layout. In other words, in respect of sediment reduction benefit, if terraces are laid out longitudinally in a river basin, they have better sediment reduction effect at the upstream than at the downstream; if terraces are laid out at one cross section, they have better sediment reduction effect at the upper area than at the lower area.

In the RUSLE, the Supporting-practice factor $(\mathrm{P})$ is used to measure the influence of the soil and water conservation measures, including terraces, on the soil erosion. Research results show that (Wu et al., 2004; Liu et al., 2011), the sediment reduction benefit of the level terraces in the Loess Plateau could reach $88 \%$, so the $\mathrm{P}$ value of the level terraces was taken as 0.12 , and that of the other types of land was taken as 1 (Figure $2 \mathrm{f}$ ). The existing land use data do not contain the spatial distribution information of terraces, but the area of terraces in all counties of the Loess Plateau can be obtained; therefore, some scholars (Xie, 2008) proposed to infer the factor of soil and water conservation measures $(\mathrm{P})$ using the ratio of the area of terraces used to the total land area:

$$
P=\left(1-\frac{S_{t}}{S} \times \alpha\right)
$$

where $S_{t}$ is the area of terrace, $\mathrm{km}^{2} ; S$ is the total area of land, $\mathrm{km}^{2} ; \alpha$ is the sediment reduction benefit of terraces, taken as 0.12 .

\section{Results and analysis}

\subsection{Actual soil erosion modulus and minimum possible soil erosion modulus in the Loess Plateau}

The calculated actual soil erosion modulus and minimum possible soil erosion modulus in the Loess Plateau are shown in Figure 3. In respect of spatial distribution, it can be seen that the areas with maximum actual soil erosion modulus and minimum possible soil erosion modulus are concentrated in the hilly-gully area and plateau-gully area in the hinterland of the Loess Plateau. 


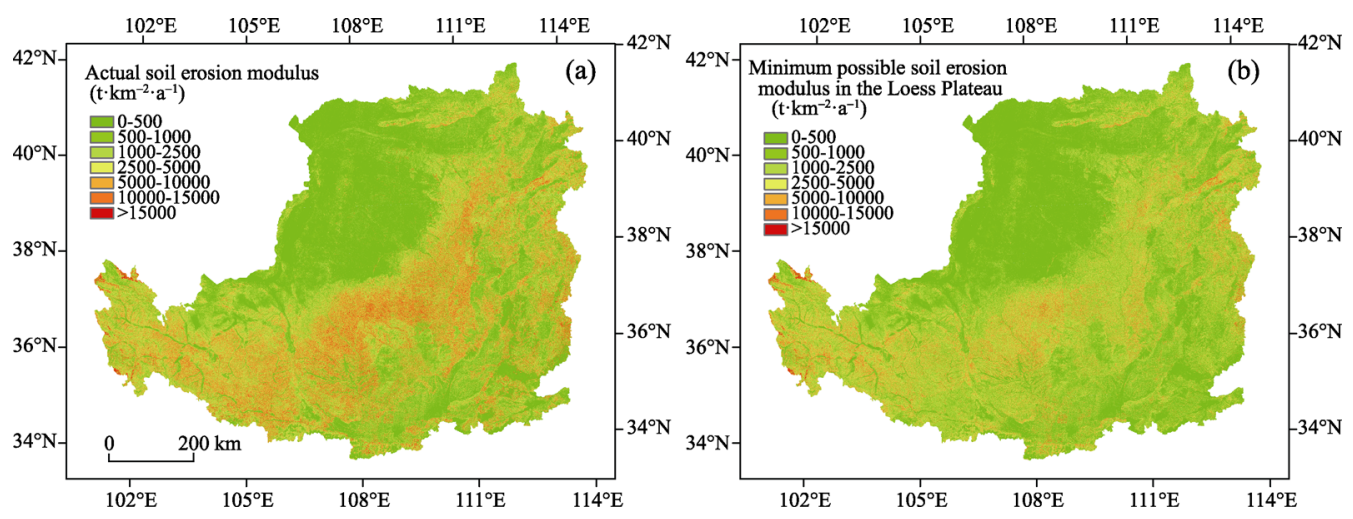

Figure 3 Actual soil erosion modulus and minimum possible soil erosion modulus in the Loess Plateau

Statistics was made for the average actual soil erosion modulus and minimum possible soil erosion modulus in various zoned areas using the Zonal Statistics tool in the ArcGIS (Table 2). For the whole Loess Plateau, the average actual soil erosion modulus is 3355 $\mathrm{t} \cdot \mathrm{km}^{-2} \cdot \mathrm{a}^{-1}$, and the average minimum possible soil erosion modulus is $1921 \mathrm{t} \cdot \mathrm{km}^{-2} \cdot \mathrm{a}^{-1}$, decreasing by $42.74 \%$. For different zoned areas, the plateau-gully area has the maximum decrease magnitude, which reaches $51.80 \%$, whereas the river valley-plain area has the minimum decrease magnitude, which is $28.98 \%$.

Table 2 Actual soil erosion modulus and minimum possible soil erosion modulus in all zones

\begin{tabular}{lccc}
\hline \multicolumn{1}{c}{ Zoning } & $\begin{array}{c}\text { Actual soil erosion } \\
\text { modulus }\left(\mathrm{t} \cdot \mathrm{km}^{-2} \cdot \mathrm{a}^{-1}\right)\end{array}$ & $\begin{array}{c}\text { Minimum possible soil erosion } \\
\text { modulus }\left(\mathrm{t} \cdot \mathrm{km}^{-2} \cdot \mathrm{a}^{-1}\right)\end{array}$ & $\begin{array}{c}\text { Decreasing } \\
\text { range }(\%)\end{array}$ \\
\hline River valley-plain area & 1377 & 978 & 28.98 \\
Windy-sandy area & 465 & 311 & 33.12 \\
Forested area & 3436 & 1863 & 45.78 \\
Hilly-gully area & 4997 & 2477 & 50.43 \\
Plateau-gully area & 5417 & 2611 & 51.80 \\
Soil-rocky mountainous area & 3824 & 2650 & 30.70 \\
Whole Loess Plateau & 3355 & 1921 & 42.74 \\
\hline
\end{tabular}

Soil loss tolerance refers to the maximum soil erosion intensity allowed for maintaining soil fertility and land productivity in a long period (Li et al., 2005), and it is a criterion for judging whether soil and water loss occurs in an area; the soil loss tolerance currently used for the Loess Plateau is $1000 \mathrm{t} \cdot \mathrm{km}^{-2} \cdot \mathrm{a}^{-1}$ (Zhang et al., 2011). Areas with soil erosion modulus less than $1000 \mathrm{t} \cdot \mathrm{km}^{-2} \cdot \mathrm{a}^{-1}$ are slight erosion areas, where no soil and water conservation measures need to be laid out in general; and areas with soil erosion modulus more than $1000 \mathrm{t} \cdot \mathrm{km}^{-2} \cdot \mathrm{a}^{-1}$ are areas with light and more severe erosion, where soil and water conservation measures are generally needed. It can be seen from the statistics in Table 2 that, under the capacity of soil and water conservation measures, the minimum possible soil erosion modulus in the Loess Plateau is still greater than the soil loss tolerance in the region. The authors made statistics for the percentages of the slight erosion areas and the light and more severe erosion areas under the actual condition and the capacity of soil and water conservation measures respectively (Table 3 ). Under the actual condition, the percentages of the slight erosion areas and the light and more severe erosion areas in the Loess Plateau are $50.48 \%$ and $49.52 \%$, respectively; under the capacity of soil and water conservation meas- 
ures, the percentage of the slight erosion areas increases to $57.71 \%$, while the percentage of the light and more severe erosion areas decreases to $42.29 \%$ accordingly.

Table 3 Ratios of different erosion types under actual conditions and under capacity of soil and water conservation measures

\begin{tabular}{|c|c|c|c|c|}
\hline \multirow[t]{2}{*}{ Zoning } & \multicolumn{2}{|c|}{ Under the actual condition (\%) } & \multicolumn{2}{|c|}{$\begin{array}{l}\text { Under capacity of soil and water } \\
\text { conservation measures }(\%)\end{array}$} \\
\hline & Slight erosion & Light or above & Slight erosion & Light or above \\
\hline River valley-plain area & 72.89 & 27.11 & 75.90 & 24.10 \\
\hline Windy-sandy area & 87.27 & 12.73 & 90.38 & 9.62 \\
\hline Forested area & 45.16 & 54.84 & 52.77 & 47.23 \\
\hline Hilly-gully area & 31.66 & 68.34 & 43.57 & 56.43 \\
\hline Plateau-gully area & 37.38 & 62.62 & 46.58 & 53.42 \\
\hline Soil-rocky mountainous area & 40.81 & 59.19 & 46.94 & 53.06 \\
\hline Loess Plateau & 50.48 & 49.52 & 57.71 & 42.29 \\
\hline
\end{tabular}

\subsection{Soil erosion control degree of the Loess Plateau}

The soil erosion control degree of the whole Loess Plateau was calculated according to the concept of soil erosion control degree (Figure 4), and the average soil erosion control degree of the Loess Plateau is 0.57 , belonging to moderate governance level. The areas with high governance degree are the river valley-plain area, soil-rocky mountainous area, and windy-sandy area, with soil erosion control degrees of $0.71,0.69$, and 0.67 , respectively. The soil erosion control degrees of the hilly-forested area and hilly-gully area are 0.54 and 0.50 , respectively, belonging to moderate governance level. Nevertheless, the plateau-gully area has relatively low governance degree, with soil erosion control degree of 0.48 (Figure 4).

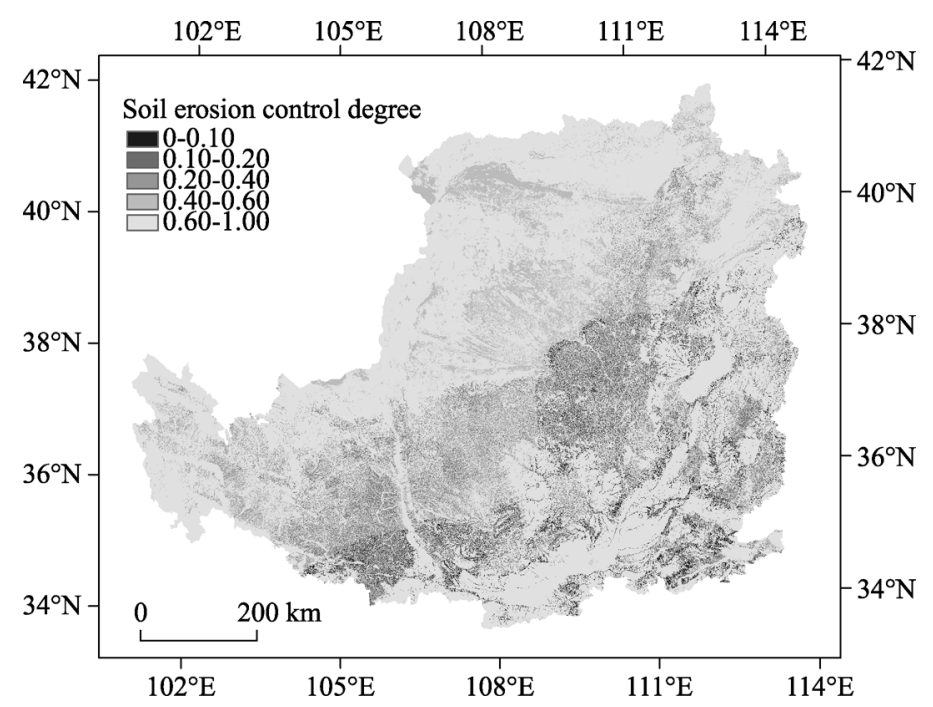

Figure 4 Soil erosion control degree in the Loess Plateau

\subsection{Land use changes under actual condition and capacity of soil and water conserva- tion measures}

Statistics was made for the land use structure in the whole Loess Plateau under the actual 
condition and the capacity of soil and water conservation measures, respectively (Table 4). Under the actual condition, the percentages of terrace, slope farmland, forestland, and grassland in the Loess Plateau are $4.36 \%, 22.35 \%, 14.99 \%$, and $41.75 \%$, respectively. Nevertheless, under the capacity of soil and water conservation measures, the percentages of terraces, slope farmland, forestland, and grassland are $19.03 \%, 0.00 \%, 19.33 \%$, and $49.82 \%$, respectively. In the whole Loess Plateau, the percentage of the terrace area is increased from $4.36 \%$ under the actual condition to $19.03 \%$ under the capacity of soil and water conservation measures, and the forest and grass coverage is increased from $56.74 \%$ to $69.15 \%$.

Table 4 Land use structure under actual condition and under capacity of soil and water conservation measures in the Loess Plateau

\begin{tabular}{|c|c|c|c|c|}
\hline \multirow{2}{*}{ Land use type } & \multicolumn{2}{|c|}{ Under the actual condition } & \multicolumn{2}{|c|}{$\begin{array}{l}\text { Under capacity of soil and water conservation meas- } \\
\text { ures }\end{array}$} \\
\hline & Area $\left(10^{4}\right.$ ha $)$ & Percentage $(\%)$ & Area $\left(10^{4}\right.$ ha $)$ & Percentage (\%) \\
\hline Paddy field & 58.75 & 0.91 & 58.74 & 0.91 \\
\hline Irrigated land & 288.72 & 4.47 & 288.72 & 4.47 \\
\hline Dam farmland & 28.63 & 0.44 & 28.63 & 0.44 \\
\hline Terrace & 281.85 & 4.36 & 1229.31 & 19.03 \\
\hline Slope farmland & 1443.91 & 22.35 & 0.00 & 0.00 \\
\hline Forestland & 968.28 & 14.99 & 1248.72 & 19.33 \\
\hline Grassland & 2697.69 & 41.75 & 3219.16 & 49.82 \\
\hline Others & 693.63 & 10.73 & 388.18 & 6.01 \\
\hline
\end{tabular}

\subsection{Grain yield change under capacity of soil and water conservation measures}

According to the land use interpretation results and the terrace and check dam survey data (YRBMC, 2011), there were $58.75 \times 10^{4}$ ha of paddy field, $288.72 \times 10^{4}$ ha of irrigated land, $28.63 \times 10^{4}$ ha of dam farmland, $281.85 \times 10^{4}$ ha of terraces, and $1443.91 \times 10^{4}$ ha of slope farmland in total in the Loess Plateau in 2010. The average per unit yields were 12,000 $\mathrm{kg} \cdot \mathrm{ha}^{-1}$ for paddy field, $6500 \mathrm{~kg} \cdot \mathrm{ha}^{-1}$ for irrigated land, $4500 \mathrm{~kg} \cdot \mathrm{ha}^{-1}$ for dam farmland, $2100 \mathrm{~kg} \cdot \mathrm{ha}^{-1}$ for terraces, and $1050 \mathrm{~kg} \cdot \mathrm{ha}^{-1}$ for slope farmland, respectively. Calculation based on this shows that the total grain output in the Loess Plateau under the actual condition is $4818.51 \times 10^{4} \mathrm{t}$, and that the slope farmland accounts for $2 / 3$ of total area of farmlands but they contribute only $1 / 3$ to the grain yield. The total population in the Loess Plateau was $11,517.52 \times 10^{4}$ in 2010 , so the per capita grain available under the actual condition was 418 $\mathrm{kg} \cdot \mathrm{a}^{-1}$. Under the capacity of soil and water conservation measures, the areas of paddy field, irrigated land and dam farmland did not change, but the area of terraces increased to $1229.31 \times 10^{4}$ ha and that of slope farmland decreased to 0 ; the calculated total grain yield in the Loess Plateau increased to $5291.95 \times 10^{4} \mathrm{t}$, and the per capita grain available could increase to $459 \mathrm{~kg} \cdot \mathrm{a}^{-1}$.

\subsection{Influence of check dams on erosion-induced sediment yield}

Check dams are main gully governance works in the Loess Plateau, and the suitable scale of check dams under the capacity of soil and water conservation measures was not taken into 
account. The reason is that check dams have less influence on erosion but much influence on sediment yield. The influence of a check dam on soil erosion is primarily reflected in two aspects: one is shortening the slope length to "submerge" the bared slope areas with great soil erosion modulus in the lower part of the river basin, and to reduce the soil erosion amount in the controlled areas. The other is retaining water and sediment to decrease the flow rate of gully runoff and thus to reduce scouring downstream check dams. The influence of the siltation by a check dam on the slope soil erosion can be evaluated using the established typical slope in hilly-gully area of the Loess Plateau and the RUSLE (Figure 5).

According to the calculation results in section 2.3.2, the rainfall-runoff erosivity $(\mathrm{R})$ of the Loess Plateau was taken as $1265 \mathrm{MJ} \cdot \mathrm{mm} \cdot \mathrm{ha}^{-1} \cdot \mathrm{h}^{-1} \cdot \mathrm{a}^{-1}$. The soil erodibility (K) was taken as $0.040 \mathrm{t} \cdot \mathrm{ha} \cdot \mathrm{h} \cdot \mathrm{ha}^{-1} \cdot \mathrm{MJ}^{-1} \cdot \mathrm{mm}^{-1}$. The LS factor was calculated with Eqs. (5), (6) and (7). The $\mathrm{C}$ values for dam farmland, terraces, slope farmland, and grassland were taken as $0.25,0.40$, 0.40 , and 0.09 , respectively. The factor of soil and water conservation measures $(\mathrm{P})$ for terraces was taken as 0.12 .

Under the typical slope conditions shown in Figure 5, if there is no dam farmland (Figure $5 \mathrm{a}$ ), the soil erosion modulus is $5617 \mathrm{t} \cdot \mathrm{km}^{-2} \cdot \mathrm{a}^{-1}$ in the area above the hillock borderline, below which the soil erosion modulus is $8528 \mathrm{t} \cdot \mathrm{km}^{-2} \cdot \mathrm{a}^{-1}$, and the average soil erosion modulus of the slope is $6864 \mathrm{t} \cdot \mathrm{km}^{-2} \cdot \mathrm{a}^{-1}$. If there is a dam farmland (Figure $5 \mathrm{~b}$ ), and it is assumed that the siltation thickness in the dam farmland is $4.2 \mathrm{~m}$, then the area of the dam farmland accounts for $4.76 \%$ of the total area, thus in the area above the hillock borderline, the soil erosion modulus does not change, still being $5617 \mathrm{t} \cdot \mathrm{km}^{-2} \cdot \mathrm{a}^{-1}$, but below the hillock borderline, it decreases to $7153 \mathrm{t} \cdot \mathrm{km}^{-2} \cdot \mathrm{a}^{-1}$, and the average soil erosion modulus of the slope decreases to $6275 \mathrm{t} \cdot \mathrm{km}^{-2} \cdot \mathrm{a}^{-1}$. Compared with the soil erosion modulus in the case without dam farmland, the soil erosion modulus has a decrease magnitude of $8.58 \%$, which is relatively low.
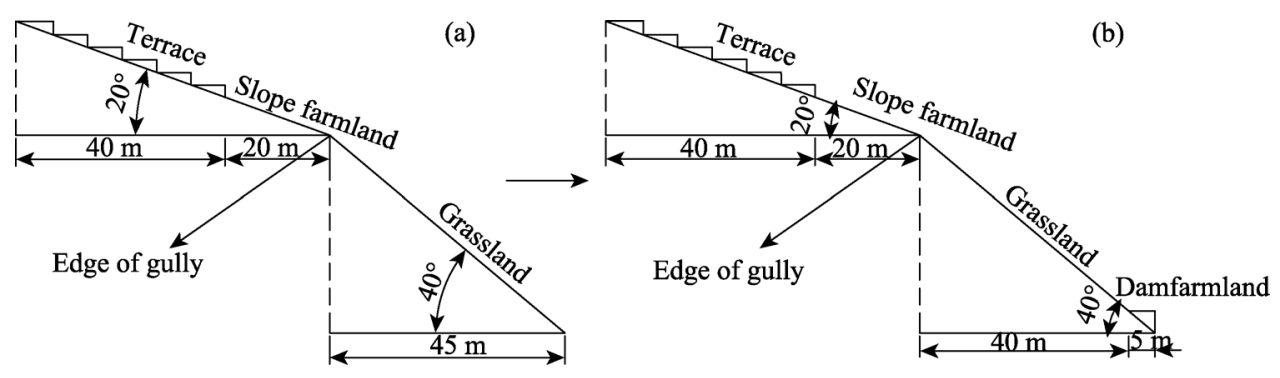

Figure 5 Effect of deposition of check dams on slope soil erosion (a. without dam farmland, b. with dam farmland)

The sediment delivery ratio (SDR) can reflect the influence of soil and water conservation measures, including check dams, on sediment transport process. In natural condition, the SDR in loess hilly-gully areas is generally close to 1 . The SDRs in typical river basins were calculated, based on the collected siltation data of key dams in the typical river basins in the middle reaches of the Yellow River, as well as the configuration ratios and control area ratios of the key dams, medium-sized dams and small-sized dams (Table 5). The results show that, the SDRs in the typical rivers in the middle reaches of the Yellow River decrease to about 0.62 . 
Table 5 Sediment delivery rate in the major rivers at the middle reaches of the Yellow River

\begin{tabular}{lcccc}
\hline River (hydrometric station) & Sediment load $\left(10^{4} \mathrm{t}\right)$ & Deposition $\left(10^{4} \mathrm{t}\right)$ & Erosion $\left(10^{4} \mathrm{t}\right)$ & $\mathrm{SDR}$ \\
\hline Tuwei river (Gaojiachuan) & 1713.51 & 271.09 & 1984.60 & 0.70 \\
Dali river (Suide) & 2174.56 & 1119.47 & 3294.03 & 0.56 \\
Jialu river (Shenjiawan) & 875.37 & 223.42 & 1098.79 & 0.64 \\
Chabagou river (Caoping) & 71.75 & 131.40 & 203.15 & 0.33 \\
Wuding river (Baijiachuan) & 4930.95 & 5555.41 & 10486.36 & 0.44 \\
Gushanchuan river (Gaoshiya) & 1208.44 & 298.25 & 1506.70 & 0.59 \\
Huangfuchuan river (Huangfu) & 3203.57 & 193.59 & 3397.16 & 0.87 \\
Kuye (Wenjiachuan) & 6779.99 & 274.16 & 7054.15 & 0.82 \\
\hline
\end{tabular}

\section{Discussion and conclusions}

\subsection{Discussion}

Compared with soil and water loss governance degree, soil erosion control degree can better reflect the actual governance level of a river basin, and is applicable to slope scale, river basin scale and region scale. On the slope scale, the change in soil erosion amount was simulated under different slope governance conditions by establishing a theoretical model for slopes (Gao et al., 2012), thereby the slope governance approach of the minimum possible soil erosion modulus was determined, and with the existing slope governance being taken into account, the slope governance degree can be determined. On the small catchment scale, finer land use classification results can be obtained. For example, QuickBird images can be used to accurately identify the distribution of terraces and slope farmlands (Li et al., 2015), and even to obtain the changes of terrain caused by soil and water conservation measures, which may lead to the change in LS factor (Gao et al., 2013). In addition, on the slope and small catchment scales, it is even simpler and more accurate to determine the capacity of soil and water conservation measures. Therefore, the capacity of soil and water conservation measures can be used to rapidly evaluate the governance degrees of slopes and small catchments. On the river basin and region scales, the key to calculating soil erosion control degree is to reasonably determine the capacity of soil and water conservation measures. For the whole Loess Plateau, research efforts on the suitability of forestland are currently relatively weak, so scientifically identifying suitable areas for forestland can improve the calculation accuracy of soil erosion control degree.

Soil erosion control degree is based on the concept of soil erosion modulus, so it is very important to accurately calculate soil erosion modulus. There are many methods for determining soil erosion modulus, e.g., use of measured runoff sediment data, rainfall simulation, field survey, radioactive isotope, and mathematical model. The RUSLE was used for calculating soil erosion modulus in this paper; although the limitation to application of the RUSLE in the Loess Plateau was corrected to the maximum extent possible, the calculated erosion amount still has some deviation due to weak research efforts on the $\mathrm{C}$ value in China. Moreover, the RUSLE can only be used to calculate water erosion modulus, but some parts of the Loess Plateau belong to wind erosion areas, and there is currently lack of an effective calculation model for complex soil erosion modulus for wind erosion and water erosion, so the change in wind erosion modulus was not taken into account in this study, resulting in too 
small soil erosion modulus calculated in windy-sandy areas.

\subsection{Conclusions}

The average soil erosion modulus under actual condition in the whole Loess Plateau is 3355 $\mathrm{t} \cdot \mathrm{km}^{-2} \cdot \mathrm{a}^{-1}$, the average minimum possible soil erosion modulus is $1921 \mathrm{t} \cdot \mathrm{km}^{-2} \cdot \mathrm{a}^{-1}$, and the soil erosion control degree is 0.57 , belonging to moderate level. In respect of zoned areas, the areas with high governance degree are the river valley-plain area, soil-rocky mountainous area, and windy-sandy area, whereas the hilly-forest areas, hilly-gully area, and plateau-gully area have lower governance degrees. In respect of river basins, the Dahei River, the Huangfuchuan River, the Qingshui River, the Kuye River and the Pianguang River basins have higher soil erosion control degrees, whereas the Qingjian River, the Wuding River, the Jialu River and the Yanhe River basins have lower soil erosion control degrees.

Comparison between the actual condition and the capacity of soil and water conservation measures shows that the percentage of slight erosion areas in the whole Loess Plateau is increased from $50.48 \%$ under the actual condition to $57.71 \%$ under the capacity of soil and water conservation measures. The forest and grass coverage is increased from $56.74 \%$ under the actual condition to $69.15 \%$ under the capacity of soil and water conservation measures. The per capita grain available is increased from $418 \mathrm{~kg} \cdot \mathrm{a}^{-1}$ under the actual condition to 459 $\mathrm{kg} \cdot \mathrm{a}^{-1}$ under the capacity of soil and water conservation measures.

\section{References}

Angulo-Martínez M, Beguería S, 2009. Estimating rainfall erosivity from daily precipitation records: A comparison among methods using data from the Ebro Basin (NE Spain). Journal of Hydrology, 379(1/2): 111-121.

Bullock A, King B, 2011. Evaluating China's slope land conversion program as sustainable management in Tianquan and Wuqi counties. Journal of Environmental Management, 92: 1916-1922.

Fu B J, Liu Y, Lu Y H et al., 2011. Assessing the soil erosion control service of ecosystems change in the Loess Plateau of China. Ecological Complexity, 8: 284-293.

Dotterweich M, 2013. The history of human-induced soil erosion: Geomorphic legacies, early descriptions and research, and the development of soil conservation: A global synopsis. Geomorphology, 201: 1-34.

Gao H D, Li Z B, Li P et al., 2012. Quantitative study on influences of terraced field construction and check-dam siltation on soil erosion. Journal of Geographical Sciences, 22(5): 946-960.

Gao H D, Li Z B, Li P et al., 2013. Concept and calculation methods of erosion control degree: A case study of the Wangmaogou watershed. Science of Soil and Water Conservation, 11(1): 17-24. (in Chinese)

Gunther F, Nachtergaele Freddy N, Sylvia P et al., 2008. Global Agro-ecological Zones Assessment for Agriculture (GAEZ 2008). IIASA, Laxenburg, Austria and FAO, Rome, Italy.

Jiang D S, 1997. Soil Erosion and Control Model in the Loess Plateau. Beijing: China Water \& Power Press, 106-120. (in Chinese)

Jiao J Y, Wang Z J, Zhao G J et al., 2014. Changes in sediment discharge in a sediment-rich region of the Yellow River from 1955 to 2010: implications for further soil erosion control. Journal of Arid Land, 6(5): 540-549.

Jiao J Y, Zou H Y, Jia Y F et al., 2009. Research progress on the effects of soil erosion on vegetation. Acta Ecologica Sinica, 29: 85-91.

Li L, Zhou Z H, Liu G C, 2005. The present situation and some thoughts of soil loss tolerance study. Advances in Earth Science, 20(10): 1127-1134. (in Chinese)

Li R, Yang W Z, Li B C, 2008. Research Progress and Prospect of the Chinese Loess Plateau. Beijing: Science Press, 183-211. (in Chinese)

Li Z, Zhang Y, Zhu Q K et al., 2015. Assessment of bank gully development and vegetation coverage on the Chinese Loess Plateau. Geomorphology, 228(1): 462-469.

Liu J Y, Kuang W H, Zhang Z X et al., 2014. Spatiotemporal characteristics, patterns, and causes of land-use changes in China since the late 1980s. Journal of Geographical Sciences, 24(2): 195-210.

Liu S L, Wang C, Zhang X L et al., 2011. Soil and water conservation effect of different terrace configurations in land consolidation project. Journal of Soil and Water Conservation, 25(4): 59-68. (in Chinese) 
Liu X Y, Wang F G, Yang S T et al., 2014. Sediment reduction effect of level terrace in the hilly-gully region in the Loess Plateau. Journal of Hydraulic Engineering, 45(7): 793-780. (in Chinese)

McCool D K, Foster G R, Mutchler C K et al., 1989. Revised slope length factor for the universal soil loss equation. Transactions of the American Society of Agricultural Engineers, 32: 1571-1576.

Ministry of Public Security Authority of the People's Republic of China (NBS, PRC), 2013. The National Counties Population Statistics Yearbook 2011. Beijing: Qunzhong Press, 121-219. (in Chinese)

Ministry of Water Resources of the People's Republic of China (MWR, PRC), Chinese Academy of Sciences, Chinese Academy of Engineering, 2010. Water Loss and Soil Erosion and Ecological Security of China: The Loess Plateau. Beijing: Science Press, 28-59. (in Chinese)

National Bureau of Statistics of the People's Republic of China, 2012. China County Statistical Yearbook 2012. Beijing: China Statistics Press, 10-426. (in Chinese)

Ran D C, 2006. Water and sediment variation and ecological protection measures in the middle reach of the Yellow River. Resources Science, 28(1): 93-100. (in Chinese)

Renard K G, Foster G R, Gleen W et al., 1997. Predicting soil erosion by water: A guide to conservation planning with the revised universal soil loss equation (RUSLE). In: U.S. Department of Agriculture Agricultural Handbook No. 703. US Department of Agriculture, Washington, DC.

Su C L, Liang Y, Li D C et al., 2011. Concept and evaluation methodology of watershed management and recovery degree in red soil region. Soils, 43(3): 466-475. (in Chinese)

Sun W Y, Shao Q Q, Liu J Y et al., 2014. Assessing the effects of land use and topography on soil erosion on the Loess Plateau in China. Catena, 121: 151-163.

Upper and Middle Reaches of the Yellow River Administrative Bureau, 2011. Introduction to the Soil and Water Conservation of Yellow River Basin. Zhengzhou: Yellow River Water Conservancy Press, 64-96. (in Chinese)

Wang F, Mu X M, Li R et al., 2015. Co-evolution of soil and water conservation policy and human-environment linkages in the Yellow River Basin since 1949. Science of the Total Environment, 508: 166-177.

Williams J R, Jones C A, Kiniry J R et al., 1989. The EPIC crop growth model. Transactions of the ASAE, 32(2): 497-511.

Wu F Q, Zhang Y B, Wang J, 2004. Study on the benefits of level terrace on soil and water conservation. Science of Soil and Water Conservation, 2(1): 34-37. (in Chinese)

Xie H X, 2008. Study on the spatio-temporal change of soil loss and on the assessment of impacts on environment of soil and water conservation in Yanhe basin [D]. Xi'an: Shaanxi Normal University. (in Chinese)

Xie W C, Li T H, 2012. Research comment on watershed sediment delivery ratio. Acta Scientiarum Naturalium Universitatis Pekinensis, 48(4): 685-694. (in Chinese)

Xu J X, Sun J, 2004. Effect of erosion control measures on sediment delivery ratio. Advances in Water Science, 15(1): 29-34. (in Chinese)

Yao W Y, Ran D C, Chen J N, 2013. Recent changes in runoff and sediment regimes and future projections in the Yellow River basin. Advances in Water Science, 24(5): 607-616. (in Chinese)

Yellow River Basin Monitoring Center (YRBMC) of Water-Soil Conservation and Eco-Environment, 2011. The Middle and Upper Reaches of the Yellow River Survey of Soil and Water Conservation Measures. Xi'an: Upper and Middle Yellow River Bureau. (in Chinese)

Yellow River Conservancy Commission of the Ministry of Water Resources, 2013. Yellow River Basin Comprehensive Planning (2012-2030). Zhengzhou: Yellow River Water Conservancy Press, 1-10. (in Chinese)

Zhang H M, Yang Q K, Li R et al., 2013. Extension of a GIS procedure for calculating the RUSLE equation LS factor. Computers \&Geosciences, 52: 177-188.

Zhang S J, Jiao J Y, 2011. Soil loss tolerance in the Loess Plateau based on the healthy function of the lower reaches of the Yellow River. Science of Soil and Water Conservation, 9(1): 9-15. (in Chinese)

Zhang X P, Zhang L, Wang Y et al., 2009. Tempo-spatially responses of the annual streamflow to LUCC in the middle reaches of Yellow River, China. Science of Soil and Water Conservation, 7(1): 19-26. (in Chinese)

Zhang Y, Liu B Y, Shi P J et al., 2001. Crop cover factor estimating for soil loss prediction. Acta Ecologica Sinica, 21(7): 1050-1056. (in Chinese)

Zhang Y, Liu B Y, Zhang Q C et al., 2003. Effect of different vegetation types on soil erosion by water. Acta Botanica Sinica, 45(10): 1204-1209.

Zhang Y X, Gao J N, Shao H et al., 2014. The terraced fields environmental impact assessment in data-scarce areas based on the embedded terraced module SWAT model. Nature Environment and Pollution Technology, 13(2): 283-288.

Zheng J Y, Yin Y H, Li B Y, 2010. A new scheme for climate regionalization in China. Acta Geographica Sinica, 65(1): 3-12. (in Chinese)

Zhao L S, Liang X L, Wu F Q, 2014. Soil surface roughness change and its effect on runoff and erosion on the Loess Plateau of China. Journal of Arid Land, 6(4): 400-409.

Zhu T X, 2012. Gully and tunnel erosion in the hilly Loess Plateau region, China. Geomorphology, 153/154: 144-155. 